\title{
A new species of Litomosoides (Nematoda: Onchocercidae), parasite of Nectomys palmipes (Rodentia: Cricetidae: Sigmodontinae) from Venezuela: description, molecular evidence, Wolbachia pipientis screening
}

\author{
Ricardo Guerrero ${ }^{1}$, Odile Bain ${ }^{2}$, Coralie Martin $^{3}$ and Michela Barbuto ${ }^{4}$ \\ ${ }^{1}$ Laboratorio de Biología de Vectores y Parásitos, Instituto de Zoología y Ecología Tropical, Universidad Central de Venezuela, \\ P.O. Box 47058, Caracas, 1041A, Venezuela; \\ ${ }^{2}$ UMR 7205 CNRS, Muséum National d'Histoire Naturelle, Parasitologie comparée, 61 rue Buffon, CP52, 75231 Paris Cedex 05, \\ France; \\ ${ }^{3}$ INSERM, FRE 3206 CNRS, Muséum National d'Histoire Naturelle, Parasitologie comparée, 61 rue Buffon, CP52, 75231 Paris \\ Cedex 05, France; \\ ${ }^{4}$ ZooPlantLab, Università degli Studi Milano Bicocca, Dipartimento di Biotecnologie e Bioscienze, Piazza della Scienza 2, 20126 \\ Milano, Italy
}

\begin{abstract}
The onchocercid filaria Litomosoides taylori sp. n. is described from the sigmodontine cricetid Nectomys palmipes Allen et Chapman in northeast Venezuela. A voucher specimen of the new species was used for molecular analysis of the coxI and $12 \mathrm{~S}$ rDNA genes, and screened for the presence of the endobacterium Wolbachia pipientis. Litomosoides taylori belongs to the "sigmodontis group" of Litomosoides and a combination of characters can be used to distinguish it from the remaining 18 species forming this group. Among the five Nectomys species, all living near running water, N. squamipes also harbours Litomosoides species, L. khonae in Brazil and L. navonae in Argentina. These three Litomosoides species of the "sigmodontis group" do not share any particular characters. Gene sequences of L. taylori differ from those of the five Litomosoides species available, the three of the "carinii group" being the most distant. The new species harbours $W$. pipientis, which is concurrent with the great majority of Litomosoides species screened to date.
\end{abstract}

Keywords: Litomosoides, Onchocercidae, integrative taxonomy, Wolbachia screening

Species of the filarial genus Litomosoides Chandler, 1931 (Onchocercidae) are a component of the Neotropical fauna because they are common parasites of several groups of small mammals, marsupials, rodents and bats (Chandler 1931, Bain et al. 1980, Brant and Gardner 2000, Guerrero et al. 2002, Notarnicola et al. 2010). It has been emphasized that this "zoologically non-coherent" host-spectrum (sensu Chabaud 1982) is the signature of an evolution driven by host-switching (Bain et al. 1991, Brant and Gardner 2000). Experimentally, the macronyssid mite Ornithonyssus bacoti (Hirst, 1913) has been established as intermediate host for Litomosoides species, irrespective of the mammalian host group (Guerrero et al. 2006).

The greatest biodiversity of Litomosoides is observed in parasites from phyllostomid bats and cricetid rodents of the Sigmodontinae. The species described herein is a parasite of the water rat, Nectomys palmipes Allen et
Chapman. It was collected during the course of an environmental impact study conducted in the region of Los Llanos in Venezuela, which yielded approximately 175 filarioids from 550 small mammals (Guerrero 2008).

An integrated analysis, linking morphological and molecular techniques, was used to study the filarial sample as in previous works (Junker et al. 2009). Moreover, presence of the rickettsial endosymbiont Wolbachia pipientis, often harboured by onchocercid filariae, was investigated, knowing that this bacterium has been detected in four of the five species of Litomosoides screened till present (Casiraghi et al. 2004), and tissular Wolbachia-like bacteria were identified by electron microscopy in a sixth species (Cardenas and Lanfredi 2008).

\section{MATERIALS AND METHODS}

The study area belongs to the Eastern Llanos region, and is located south of Pariaguan in the state of Anzoategui, in the 
petroleum district called San Tome. It is a Trachypogon savannah, crossed by small rivers and with patches of gallery forest or palm tree (Mauritia flexuosa) forest. Nectomys palmipes were trapped in a palm tree forest, euthanized and checked for parasites under a stereomicroscope. Universal Transverse Mercator coordinate system is used for the geographical localisation.

Recovered parasites were fixed and preserved in hot $70 \%$ ethanol for morphological studies, or in absolute ethanol for DNA analysis (Ferri et al. 2009) and screening of the bacterial endosymbiont Wolbachia pipientis (Bain et al. 2008).

Specimens were cleared in lactophenol, measured and drawn using a microscope equipped with a camera lucida. Individual measurements are given for the holotype female and allotype male. Their respective descriptions are followed by measurements of paratypes given as the mean \pm SEM. Measurement ranges are reported in Tables 2 and 3. Body length is given in millimetres; all other measurements are in micrometres. All specimens described were collected from a single host individual.

The morphological characters of the filariae were studied as described by Esslinger (1973) and Guerrero et al. (2002). The head was cut using a razor blade and observed in front view. Lateral chords and crests at vulva level were studied on transverse sections made at the level of vulva with a razor blade. The arrangement of male caudal papillae was observed on the tail in ventral view in several specimens; papillae are paired (papillae of a pair on a transverse line) or aligned (papillae of a pair more or less aligned on the ventral line). Two numbers are given for the area rugosa: the distance of the posterior end to cloaca, and the distance of the anterior end to cloaca. Host names used are consistent with Wilson and Reeder (2005) and Guerrero et al. (2011).

Parasites were deposited in the Parasitological Collection, Museo de Biologia, Universidad Central de Venezuela (Caracas) (CP-MBUCV), in the Muséum National d'Histoire Naturelle, Paris (MNHN), and a paratype in the Institute of Parasitology, BC ASCR, České Budějovice, Czech Republic.

For molecular analysis a female voucher specimen (MIB:zpl:00164) was transferred directly into absolute ethanol. DNA extract was prepared using the 5 PRIME, ArchivePure DNA Purification Kit. The filarial coxI and 12S rDNA gene sequences were generated following Folmer et al. (1994) and Casiraghi et al. (2004). The obtained sequences are about 600 and 500 bp long, respectively. PCR products were gel-purified using the 5PRIME, GelElute Extraction Kit and sequenced directly using $\mathrm{ABI}$ technology. All sequences have been deposited in the EMBL Data Library.

Sequences were checked visually with the BioEdit sequence alignment editor (version 7.0.5; Hall 1999), using GenBank nematode sequences as reference, and unambiguously aligned using Clustal X (Thompson et al. 1997). Nucleotide distances were calculated using MEGA 4.0 (Tamura et al. 2007) - options: nucleotide, Kimura 2-parameter, complete deletion, standard error computation by bootstrapping 500 replicates.

PCR screening for the presence of $W$. pipientis in the filaria was conducted following the methods described by Casiraghi et al. (2001, 2004), using general Wolbachia primers for $16 \mathrm{~S}$ rDNA. PCRs were performed under different conditions (see Casiraghi et al. 2004) to increase screening sensitivity.

\section{RESULTS}

\section{Litomosoides taylori Guerrero et Bain sp. n.}

Figs. 1, 2

Description. Medium-sized Litomosoides, male one third of length of female; body tapering at both ends. Head attenuated, concave at mouth opening. Head papillae asymmetrically arranged: four externo-labial papillae (two dorsal and two ventral, close to sagittal plane) and two salient latero-ventral cephalic papillae; amphids not salient. Buccal capsule longer than broad (length/ width 1.67-2.5), thinner in anterior part, posterior part embedded in oesophagus; external aspect of capsule wall not clearly delineated and irregular; in some specimens, a faint ring at mid-length present, more or less conspicuous depending on worm orientation (Fig. 1B, C). Buccal cavity conical anteriorly, tubular in posterior two thirds. Oesophagus apex most often dilated, followed by a constriction and a thickening just posteriorly; distinct division of oesophagus in muscular anterior and glandular posterior part, particularly in males. Nerve ring in posterior half of oesophagus. Tail long.

Female (Fig. 1): Post-oesophageal vulva and subspherical vagina. Lateral internal cuticular crest rounded in transverse section; lateral hypodermal chord narrow and thick. Tail long, thin, tip twisted and bent to left side.

Holotype: Total length 65.0, maximum width 250, at nerve ring 88, at oesophageal-intestinal junction 120 . Buccal capsule 20 long and 10.5 wide; buccal capsule ratio 1.90. Nerve ring to anterior end 410. Oesophagus 620 long. Vulva 1540 to apex. Vagina 88 long by 80 wide. Tail 500 long, width at anus 70. Paratypes $(\mathrm{n}=9)$ : Total length $54.3 \pm 1.94$, maximum width $215 \pm 8.1$, at nerve ring $81 \pm 7.2$, at oesophageal-intestinal junction $106.6 \pm 6.2$. Buccal capsule $21.7 \pm 1$ long and $11 \pm 0.5$ wide; buccal capsule ratio $2.1 \pm 0.14$. Nerve ring to anterior end $421 \pm 22.3$. Oesophagus $606 \pm 21.4$ long. Vulva $1355 \pm 63$ to apex. Vagina $102 \pm 2.1$ long by $66 \pm 2.9$ wide. Tail $437 \pm 28.5$ long; width at anus $61 \pm 4.2$.

Microfilaria (from ovejector; $n=4$ ): 58 (range 55-62) long and 3-4 wide; body attenuated at both extremities; salient cephalic hook; posterior extremity attenuated and pointed; last nucleus elongated, distant from tail tip. Sheath not identified.

Male (Fig. 2): Posterior region coiled; tail attenuated and finger-shaped, extremity rounded. Three to five pairs of caudal papillae, usually 4 pairs; papillae paired in anterior half of tail, more or less aligned in posterior half, the last reduced to an unpaired papilla; first pair adcloacal or slightly posterior; last papilla far from tail end. Left spicule with handle as long as lamina; lamina composed of a membranous folded ala and a terminal filament with rounded tip. Right spicule with slightly sclerotized terminal part composed of a non prominent dorsal heel, a distal pair of fine rods and a short membranous apical flap. 


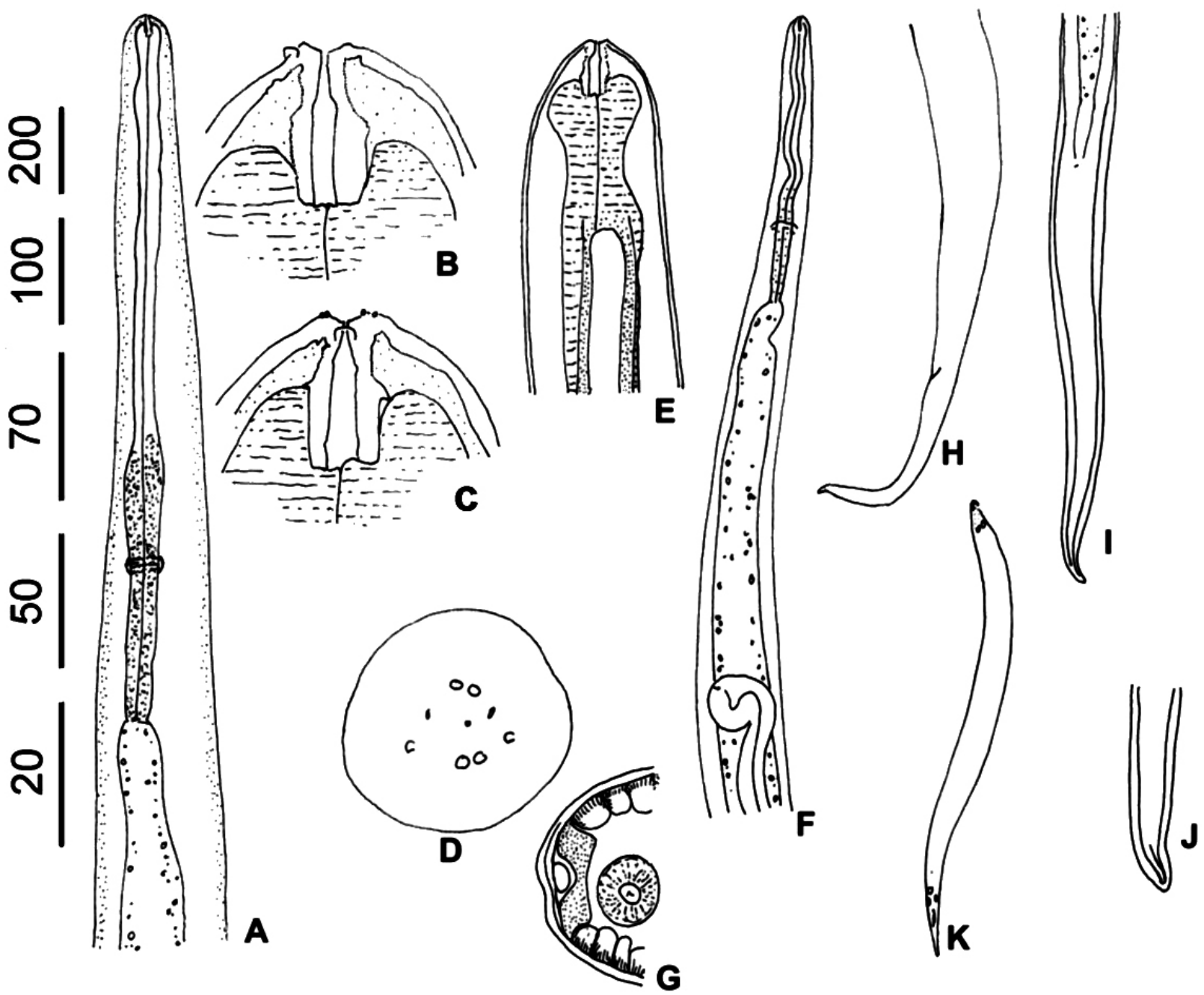

Fig. 1. Litomosoides taylori sp. n., female. A - oesophageal region, dorso-ventral view; B, C - head in ventral and lateral view, respectively (holotype); $\mathbf{D}$ - head in front view; $\mathbf{E}$ - cephalic region showing lateral internal crest and chord (holotype); $\mathbf{F}$ - anterior region, including vulva, subventral view; $\mathbf{G}$ - cross section at level of vagina (half the section is presented); $\mathbf{H}$ - posterior region, lateral view; I - tail, ventral view; $\mathbf{J}$ - twisted extremity of tail; $\mathbf{K}$ - uterine microfilaria. Scale bars: A, I $=100 \mu \mathrm{m} ; \mathrm{B}-\mathrm{D}, \mathrm{K}=20 \mu \mathrm{m}$; $\mathrm{E}, \mathrm{J}=50 \mu \mathrm{m} ; \mathrm{F}, \mathrm{H}=200 \mu \mathrm{m} ; \mathrm{G}=70 \mu \mathrm{m}$.

Area rugosa composed of transverse bands of longitudinal crests.

Allotype: Total length 20.8, maximum width 140, at nerve ring 48, at oesophageal-intestinal junction 60 . Buccal capsule 23 long and 10 wide; buccal capsule ratio 2.30. Nerve ring to anterior end 238. Oesophagus 580 long. Tail 179 long, width at anus 42. Area rugosa extends from 452 to 2132 from cloacal aperture. Left spicule 263 long, handle 130 long. Right spicule 73 long. Spicular ratio 3.36. Paratypes $(n=7)$ : Total length $18.9 \pm 0.7$, maximum width $127 \pm 5.3$, at nerve ring $54 \pm 2.2$, at oesophageal-intestinal junction $64 \pm 1.8$. Buccal capsule $20.2 \pm 0.4$ long and $9.4 \pm 0.4$ wide; buccal capsule ratio $2.16 \pm 0.07$. Nerve ring to anterior end $273 \pm 12.8$. Oesophagus $533 \pm 18.5$ long. Tail $171 \pm 3.3$ long, width at cloaca $41 \pm 1.1$. Area rugosa $433 \pm 29$ to $1963 \pm 110$ from cloacal aperture. Left spicule $257 \pm 6.2$ long, handle
$124 \pm 2.1$ long. Right spicule $81 \pm 2.3$ long. Spicular ratio $3.18 \pm 0.1$.

Type host: Nectomys palmipes Allen et Chapman, 1892 (Rodentia: Cricetidae: Sigmodontinae).

Type locality: Rio Castillito, 170 metres altitude, Municipio Jose Gregorio Monagas, Edo. Anzoategui, Venezuela. Geographic coordinates E20-310658 N957193.

Site of infection: Peritoneal and pleural cavities.

Prevalence and intensity: Three hosts examined, all infected; 29, 6 and 59 filariae per host.

Type material: Holotype female CP-MBUCV No. 6124; allotype male CP-MBUCV No. 6125; 3 male and 4 female paratypes CP-MBUCV No. 4816; 4 male and 4 female paratypes in MNHN Paris collection, accession number 44 YU. A female paratype in the Institute of Parasitology, BC ASCR, České Budějovice, Czech Republic (N-964). EMBL Data Library accession number: FR719324 for coxI and FR719325 for $12 \mathrm{~S}$ rDNA. 


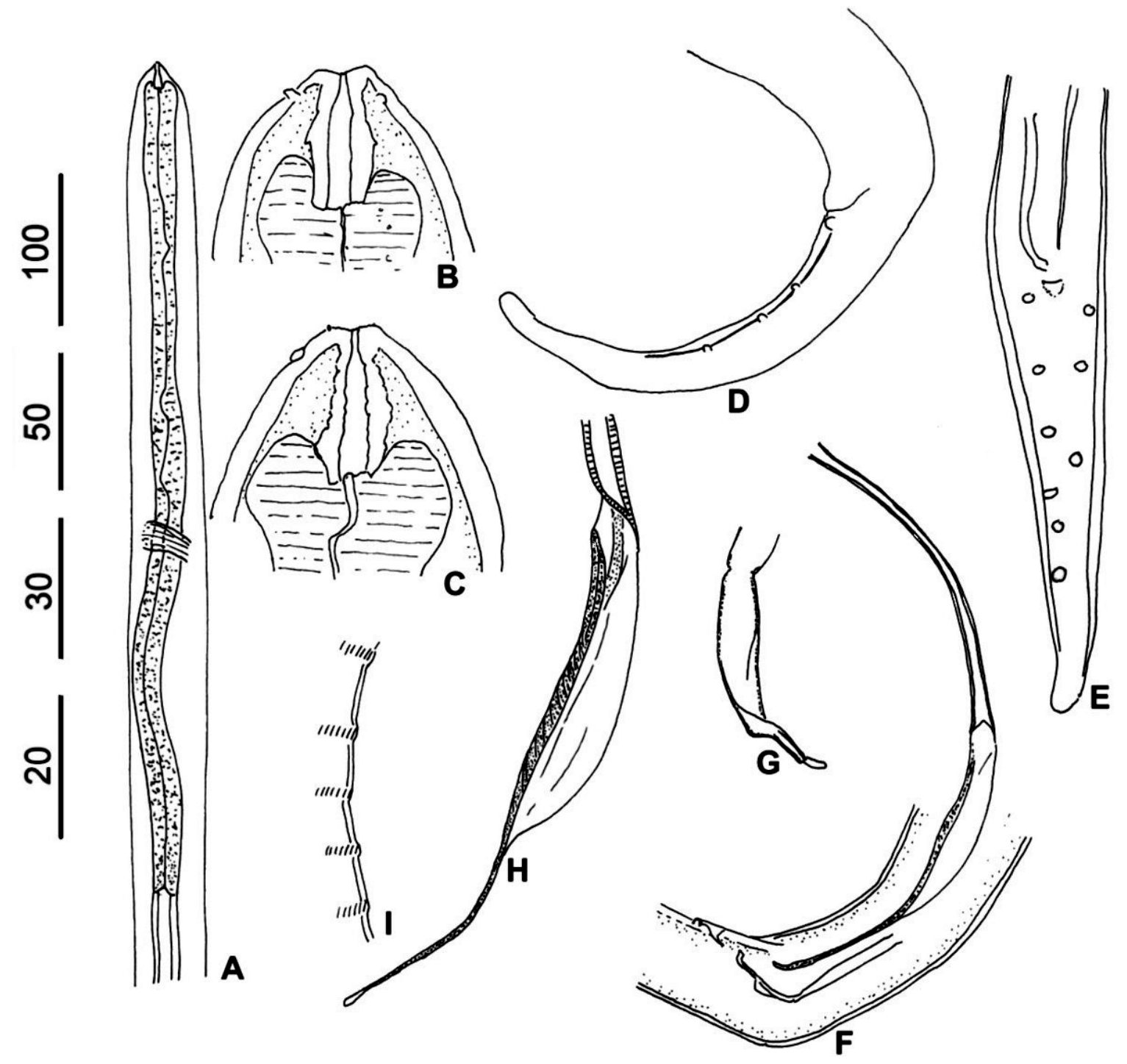

Fig. 2. Litomosoides taylori sp. n., male. A - anterior extremity, right lateral view; B - buccal capsule, ventral view; $\mathbf{C}-$ buccal capsule of another specimen, left lateral view; D - tail, left lateral view (allotype); $\mathbf{E}$ - tail, ventral view (allotype); $\mathbf{F}$ - spicules, left lateral view (allotype); $\mathbf{G}$ - distal end of right spicule, right lateral view; $\mathbf{H}$ - lamina of left spicule, left lateral view; I - detail of area rugosa at its mid-length, right lateral view (partial representation to show longitudinal crests and distance between transverse ridges). Scal bars: A $=100 \mu \mathrm{m} ; \mathrm{B}, \mathrm{C}=20 \mu \mathrm{m}$; D-F $50 \mu \mathrm{m}$; G-I $=30 \mu \mathrm{m}$.

Ety mology: The species is dedicated to Prof. David Taylor, University of Edinburg, in recognition of his dynamic collaboration during twenty years as coordinator of research programmes using Litomosoides sigmodontis as a model for filariases.

Remarks. Two morphological groups are identified in Litomosoides, the "carinii" and the "sigmodontis" groups (Bain et al. 1989). The new species belongs to the latter, based on the shape of its spicules (lamina of the left spicule with large membranous part; distal end of the right spicule not heavily sclerotized, with two rods and membranous tip). The "sigmodontis group" comprises 18 species parasitic in rodents, marsupials and bats (Table 1), all of which differ from L. taylori (Tables 2, 3). Their distinctive characters are outlined below.

Twelve species are parasites of Sigmodontinae: Litomosoides patersoni (Mazza, 1928), has shorter, stout microfilariae (35-44 long and 6 wide), a pair of precloacal papillae and its remaining caudal papillae are symmetrically arranged; it also has a complete set of head papillae and a straight female tail (Mazza 1928, Notarnicola et al. 2010). Five species have prominent amphids (Notarnicola et al. 2002, Bain et al. 1980, Notarnicola et al. 2000, Notarnicola and Navone, 2009, Notarnicola 2005). Microfilariae of three of these species are longer than 75 (55-62 in L. taylori); in addition, in L. anguyai Notarnicola, Bain 
Table 1. Species of Litomosoides of the "sigmodontis group" and the five species known only by female or microfilariae.

\begin{tabular}{|c|c|c|c|}
\hline \multirow{2}{*}{ Species } & \multicolumn{2}{|l|}{ Host } & \multirow{2}{*}{$\begin{array}{l}\text { Type } \\
\text { locality }\end{array}$} \\
\hline & Type species & Family & \\
\hline L. anguyai Notarnicola, Bain et Navone, 2002 & Oxymycterus misionalis & Cricetidae & Argentina \\
\hline L. barretti Muller, 1980 & Micoureus demararae* & Didelphidae & Brazil \\
\hline L. chagasfilhoi Moraes Neto, Lanfredi et De Souza, 1997 & Akodon cursor & Cricetidae & Brazil \\
\hline L. circularis (Linstow, 1899) & Holochilus brasiliensis $* *$ & Cricetidae & Brazil \\
\hline L. ctenomyos Brant et Gardner, 1997 & Ctenomys opimus & Ctenomyidae & Bolivia \\
\hline L. esslingeri Bain, Petit et Diagne, 1989 & Melanomys caliginosus & Cricetidae & Colombia \\
\hline L. fosteri Caballero, 1947 & Glossophaga soricina & Phyllostomidae & Panama \\
\hline L. galizai Bain, Petit et Diagne, 1989 & Oecomys trinitatis tapajinus & Cricetidae & Brazil \\
\hline L. hoplomyis Esslinger, 1973 & Hoplomys gyтпитиs & Echimyidae & Colombia \\
\hline L. kohnae Bain, Petit et Diagne, 1989 & Nectomys squamipes & Cricetidae & Brazil \\
\hline L. legerae Bain, Petit et Berteaux, 1980 & Oxymycterus quaestor & Cricetidae & Brazil \\
\hline L. leonilavazquezae Caballero, 1939 & Macrotus waterhousii & Phyllostomidae & Mexico \\
\hline L. nasuti Notarnicola et Navone, 2009 & Oxymycterus nasutus & Cricetidae & Uruguay \\
\hline L. navonae Notarnicola, 2005 & Nectomys squamipes & Cricetidae & Argentina \\
\hline L. oxymycteri Notarnicola, Bain et Navone, 2000 & Oxymycterus rufus & Cricetidae & Argentina \\
\hline L. patersoni (Mazza, 1928) & Holochilus chacarius & Cricetidae & Argentina \\
\hline L. sigmodontis Chandler, 1931 & Sigmodon hispidus & Cricetidae & USA \\
\hline L. taylori Guerrero et Bain sp. $n$. & Nectomys palmipes & Cricetidae & Venezuela \\
\hline L. teshi Esslinger, 1973 & Carollia perspicillata & Phyllostomidae & Colombia \\
\hline \multicolumn{4}{|l|}{ Male unknown } \\
\hline L. artibei Esslinger, 1973 & Artibeus jamaicensis & Phyllostomidae & Colombia \\
\hline L. chitwoodi Bain, Guerrero et Rodriguez, 2003 & Artibeus jamaicensis & Phyllostomidae & Mexico \\
\hline L. solarii Guerrero, Martin, Gardner et Bain, 2002 & Trachops cirrhosus & Phyllostomidae & Peru \\
\hline L. caliensis Esslinger, 1973 & Sturnira lilium & Phyllostomidae & Colombia \\
\hline L. colombiensis Esslinger, 1973 & Platyrrhinus dorsalis & Phyllostomidae & Colombia \\
\hline
\end{tabular}

Species of Nectomys are in bold characters; *in Guerrero et al. 2002; **in Guerrero et al. 2011.

et Navone, 2002 the male has a pair of precloacal papillae; L. legerae Bain, Petit et Berteaux, 1980 has a complete set of head papillae (4 externo-labial and 4 cephalic), buccal capsule walls with alternatingly expanded and constricted parts, and a microfilaria with a caudal filament; in L. oxymycteri Notarnicola, Bain et Navone, 2000 the fourth pair of caudal papillae is joined on the midventral line and the oesophagus is undivided. Of the two remaining species with prominent amphids, L. nasuti Notarnicola et Navone, 2009 has no apparent cephalic papillae, its buccal capsule has a conspicuous ring and the female tail carries phasmidial knobs; L. navonae Notarnicola, 2005 possesses one cephalic papilla and the male tail is longer, with six or seven pairs of caudal papillae, several of which are asymmetrically arranged. Among the five species with non-salient amphids (Bain et al. 1989, Moraes-Neto et al. 1997), the buccal capsule wall of L. galizai Bain, Petit et Diagne, 1989 is thinner in both sexes as well as longer in the male (25-30 vs. 19-22 in L. taylori); L. khonae Bain, Petit et Diagne, 1989 is a longer species with shorter microfilariae, the tail is pointed in both sexes and curved dorsally in the female; in L. chagasfilhoi Moraes-Neto, Lanfredi et de Sousa, 1997, the buccal capsule wall is thinner, the oesophagus undivided and the left spicule has a long membranous terminal sheath; L. sigmodontis Chandler, 1931, redescribed by Bain et al. (1989), has longer microfilariae $(84.5 \pm 2.9)$ and a buccal capsule with thicker, irregular and well sclerotized walls. Litomosoides esslingeri Bain, Petit et Diagne, 1989 has an irregular buccal capsule wall, a cylindrical buccal cavity, a straight tail with a conical extremity in the female, large and flat lateral chords, and microfilariae with a large sheath. Litomosoides circularis (von Linstow, 1899) has a shorter buccal capsule in the males, a pair of adcloacal papillae, the fourth pair is joined on the midventral line, and the terminal third of the left spicule is rod-like with a bevelled extremity (von Linstow 1899, Guerrero and Bain 2011). Two species are parasites of rodents other than Sigmodontinae (Esslinger 1973, Brant and Gardner 1997): Litomosoides hoplomyis Esslinger, 1973 from Echimyidae is a very small species (males 10-13 and females 18-30 long) and its buccal capsule wall is thinner but with a thick anterior part. In L. ctenomyos Brant et Gardner, 1997 from Ctenomyidae, the oesophagus is longer and undivided in the female, and caudal papillae are symmetrically arranged along the male tail right to the tip.

The single species from marsupials, L. barretti Muller, 1980, is larger, with a shorter buccal capsule; its caudal papillae are all paired and no cephalic papillae have been described (Muller 1980).

Three species are parasites of bats (Caballero 1939, 1947, Esslinger 1973): Litomosoides leonilavazquezae Caballero, 1939, of which the description is not very precise, has a shorter buccal capsule and a finger-shaped 
Table 2. Measurements of females of Litomosoides species of the "sigmodontis group" and the five species known only by female or microfilariae (body length in millimetres, other measurements in micrometres).

\begin{tabular}{|c|c|c|c|c|c|c|c|c|c|}
\hline \multirow{2}{*}{ Group } & \multirow{2}{*}{ Species } & \multirow{2}{*}{ Total length } & \multicolumn{2}{|c|}{ Buccal capsule } & \multirow{2}{*}{$\begin{array}{l}\text { Oesophagus } \\
\text { length }\end{array}$} & \multirow{2}{*}{ Vulva to apex } & \multirow{2}{*}{ Tail length } & \multicolumn{2}{|c|}{ Microfilariae } \\
\hline & & & length & width & & & & in uterus & in blood \\
\hline \multirow[t]{23}{*}{ "sigmodontis" } & anguyai* & $48.7-74.0$ & $17-24$ & $6-9$ & $624-975$ & $1093-1820$ & $272-767$ & $80-112$ & - \\
\hline & barretti* & $67.0-85.0$ & $16^{\mathrm{f}}$ & - & $670-800$ & $1300-1800$ & $400-530$ & - & $60-73$ \\
\hline & chagasfilhoi* & $86.9-95.0$ & $18-25$ & $3-4$ & $600-775$ & $1300-2257$ & $375-600$ & $61-92$ & $62-72$ \\
\hline & circularis* & 65.0 & - & - & 620 & 1300 & 690 & - & - \\
\hline & circularis $^{1}$ & $59.9-80.8$ & $15-20$ & $8-9$ & $546-667$ & $1098-1806$ & $544-633$ & $62-63$ & - \\
\hline & ctenomyos* & - & $17-20$ & $6-11$ & $833-872$ & $1125-2170$ & $593^{\mathrm{f}}$ & 72 & - \\
\hline & esslingeri* & $56.0-104.0$ & $20-24$ & $9-13$ & $384-656$ & $840-2180$ & $414-710$ & - & $65-77$ \\
\hline & fosteri* & 42.6 & 19 & 4 & 631 & 1460 & 213 & - & - \\
\hline & galizai* & $59.0-81.0$ & $20-25$ & - & $540-800$ & $1400-2130$ & $410-920$ & $52-75$ & $72-102$ \\
\hline & hoplomyis* & $18.0-30.0$ & $16-21$ & $5-8$ & $572-794$ & $750-1120$ & $233-382$ & - & $58-71$ \\
\hline & $k_{\text {honae* }}$ & $110.0-115.0$ & $16-18$ & - & $720-730$ & $1920-2350$ & 580 & $55-62$ & - \\
\hline & legerae* & $80.0-97.0$ & $21-24$ & - & $1040-1240$ & $1340-2100$ & $415-555$ & $80-83$ & $45^{\mathrm{f}}$ \\
\hline & leonilavazquezae* & $40.0-50.0$ & 16 & 6 & $516-528$ & $840-1300$ & 468 & - & $52-56$ \\
\hline & nasuti* & $37.4-47.9$ & $16-22$ & $7-10$ & $450-760$ & $850-1300$ & $215-540$ & $69-76$ & - \\
\hline & navonae* & $42.8-77.1$ & $18-25$ & $8-11$ & $580-1125$ & $1300-2300$ & $375-908$ & $62-85$ & $65-72$ \\
\hline & oxymycteri* & $43.0-70.8$ & $17-24$ & $7-11$ & 519-1023 & $1071-1650$ & $293-590$ & $75-103$ & - \\
\hline & patersoni* & $61.0-92.0$ & - & - & 900 & 1100 & $910^{\mathrm{f}}$ & - & $35-46$ \\
\hline & patersoni $i^{2}$ & - & $24-27$ & $9-10$ & $650-780$ & $1350-2050$ & 500 & $35-44$ & - \\
\hline & sigmodontis* & $50.0-65.0$ & $25^{\mathrm{f}}$ & - & $650^{\mathrm{f}}$ & 1250 & 625 & $100-105$ & - \\
\hline & sigmodontis $^{3}$ & 68.0 & $18-21$ & - & $690-720$ & $1100-1390$ & $270-660$ & 84.5 & $71-75$ \\
\hline & taylori sp. $\mathrm{n}$. & $43.0-65.0$ & $18-25$ & $9-13$ & $520-680$ & $1150-1595$ & $330-535$ & $55-62$ & - \\
\hline & teshi* & $84.0-92.0$ & $20-25$ & $9-11$ & $570-656$ & $950-1420$ & $296-445$ & - & $75-109$ \\
\hline & $\operatorname{tesh} i^{4}$ & $89.0-91.0$ & $20-22$ & - & $640-650$ & $960-1350$ & $360-430$ & - & - \\
\hline \multirow[t]{6}{*}{ Male unknown } & artibei* & $>4.0$ & 34 & 5 & 525 & 825 & - & - & $97-108$ \\
\hline & artibe $^{4}$ & - & $33-34$ & - & $524-527$ & $820-832$ & $120-130$ & - & - \\
\hline & chitwoodi* & 15.0 & 12 & - & 583 & 810 & 583 & - & - \\
\hline & solarii* & 52.9 & 21 & 7 & 935 & 910 & 250 & $50-60$ & - \\
\hline & caliensis* & - & - & - & - & - & - & - & $53-65$ \\
\hline & colombiensis* & - & - & - & - & - & - & - & $100-125$ \\
\hline
\end{tabular}

* from original author (see Table 1); ${ }^{\mathrm{f}}$ measured from original figure; ${ }^{1}$ Guerrero and Bain $2011 ;{ }^{2}$ Notarnicola et al. 2010; ${ }^{3}$ Bain et al. 1989; ${ }^{4}$ Cuartas-Calle and Muñoz-Arango 1999.

tail in the female, the males have a shorter tail. Litomosoides fosteri Caballero, 1947 has a buccal capsule with two thickened rings, a shorter tail in both sexes, a shorter right spicule, eight pairs of caudal papillae and a higher spicular ratio (4.8 compared to $2.93-3.75$ in L. taylori). Litomosoides teshi Esslinger, 1973 is a larger species with an asymmetrical buccal capsule and longer microfilariae (75-109 vs. 55-62 in L. taylori).

The males of the remaining six species are not known and, therefore, they cannot be assigned to the "sigmodontis" or "carinii" group. Of three of these the females are known (Esslinger 1973, Guerrero et al. 2002, Bain et al. 2003): Litomosoides artibei Esslinger, 1973 has a longer buccal capsule (34); L. solarii Guerrero, Martin, Gardner et Bain, 2002 has a tubular buccal cavity with thin capsule walls, a longer oesophagus, the vulva is situated in the oesophageal region and the microfilariae are cylindrical, with a posterior extremity that abruptly attenuates to a sharp point; $L$. chitwoodi Bain, Guerrero et Rodriguez, 2003 has a shorter buccal capsule (12). Of the remaining two species, only the microfilariae are known: L. colombiensis Esslinger, 1973 is twice as long and tapers pos- teriorly to form a narrow tail tip; L. caliensis Esslinger, 1973 has a thicker tail with a rounded extremity (Esslinger 1973).

\section{Molecular analyses}

Using an integrated taxonomical approach based both on morphological characterisation and DNA barcoding (Ferri et al. 2009), the new species was also characterised by $12 \mathrm{~S}$ rDNA and coxI sequence analysis. The datasets used for this work comprise a total of 188 sequences for coxI and 199 sequences for $12 \mathrm{~S}$ rDNA. The more closely related nematodes were detected within the genus Litomosoides itself. Among the five Litomosoides species analysed to date (Casiraghi et al. 2004), three belong to the “carinii group", L. brasiliensis Almeida, 1936, L. hamletti Sandground, 1934 and L. yutajensis Guerrero, Martin et Bain, 2003, and are more distant to the new species than those of the "sigmodontis group", L. sigmodontis and L. galizai. Litomosoides galizai (EMBL Data Library accession numbers: 12SrDNA AJ544849; coxI AJ544870), a parasite of Oecomys (see Table 1), is closest to the new species: K2P nucleotide diversity was $5.4 \%$ (standard de- 
Table 3. Measurements of males of Litomosoides species of the "sigmodontis group" (body length in millimetres, other measurements in micrometres).

\begin{tabular}{|c|c|c|c|c|c|c|c|c|}
\hline \multirow{2}{*}{ Species } & \multirow{2}{*}{ Total length } & \multicolumn{2}{|c|}{ Buccal capsule } & \multirow{2}{*}{$\begin{array}{l}\text { Oesophagus } \\
\text { length }\end{array}$} & \multirow{2}{*}{$\begin{array}{l}\text { Left } \\
\text { spicule }\end{array}$} & \multirow{2}{*}{$\begin{array}{l}\text { Right } \\
\text { spicule }\end{array}$} & \multirow{2}{*}{$\begin{array}{l}\text { Pairs of cloa- } \\
\text { cal papillae }\end{array}$} & \multirow{2}{*}{$\begin{array}{c}\text { Tail } \\
\text { length }\end{array}$} \\
\hline & & length & width & & & & & \\
\hline anguyai* & $19.1-27.4$ & $15-21$ & $6-8$ & $456-815$ & $240-370$ & $64-91$ & $1-1-3 / 4$ & $174-214$ \\
\hline barretti* & $22.0-24.4$ & - & - & $470-660$ & 333 & $100-115$ & $0-1-5$ & 230 \\
\hline chagasfilhoi* & $21.9-30.0$ & $17-22$ & $3-4$ & $513-587$ & $296-316$ & $81-94$ & $0-1-4 / 6$ & $144-188$ \\
\hline circularis* & 20.0 & - & _- & 440 & 260 & 190 & $0-0-7$ & 160 \\
\hline circularis $^{1}$ & $21.5-24.6$ & $14-16$ & 8 & $454-556$ & $250-311$ & $98-121$ & $0-1-3 / 4$ & 119-198 \\
\hline ctenomyos* & $27.0-31.0$ & $13-18$ & $7-9$ & $511-730$ & $189-385$ & $73-91$ & $0-1-8 / 9$ & $151-194$ \\
\hline esslingeri* & $15.0-25.0$ & $16-23$ & $7-11$ & $380-583$ & $255-315$ & 80-106 & $0-1-3 / 5$ & $151-200$ \\
\hline fosteri* & $20.8-21.6$ & $15-19$ & 4 & 646 & 274 & 57 & $0-0-8$ & $87-99$ \\
\hline galizai* & $17.0-19.2$ & $25-30$ & - & $610-640$ & $300-345$ & $78-82$ & $0-1-2 \& 4$ & $242-250$ \\
\hline hoplomyis* & $10.0-13.0$ & $15-19$ & $5-7$ & $604-705$ & $180-238$ & $53-77$ & $0-0-3 / 4$ & $135-171$ \\
\hline khonae* & $22.2-22.7$ & $15-17$ & - & $550-680$ & $285-305$ & $75-92$ & $0-1-3 / 4 \& 5 / 6$ & $225-280$ \\
\hline legerae* & $25.0-27.0$ & 22 & - & $720-800$ & $300-360$ & $85-90$ & $0-1-3$ & $200-248$ \\
\hline leonilavazquezae* & $19.3-19.5$ & $18-20$ & 4 & 429 & 209-229 & $82-86$ & $0-1-3$ & $73-106$ \\
\hline nasuti* & $16.3-17.9$ & $15-16$ & $7-8$ & $540-600$ & $285-300$ & $70-75$ & $0-1-3$ & $170-190$ \\
\hline navonae* & $18.1-28.0$ & $16-21$ & $6-9$ & $432-750$ & $220-375$ & $80-95$ & $0-1-5 / 6$ & $210-280$ \\
\hline oxymycteri* & $15.6-23.6$ & $18-23$ & $7-11$ & $532-980$ & $231-340$ & $80-167$ & 1 unpaired-1-4 & $186-240$ \\
\hline patersoni* & $20.0-22.0$ & - & - & 550 & 125 & 50 & $0-1-2$ & 250 \\
\hline patersoni $^{2}$ & $15.8-19.3$ & $19-22$ & $7-8$ & $510-580$ & $246-247$ & $80-87$ & $1-1-3 / 4$ & $146-275$ \\
\hline sigmodontis* & $24.0-28.0$ & 20 & - & & $185-295$ & $75-80$ & $0-0-4$ & 180 \\
\hline sigmodontis $^{3}$ & $18.1-20.1$ & 17 & - & $540-580$ & $255-295$ & $78-90$ & $0-1-3 \& 5$ & $165-170$ \\
\hline taylori sp. $\mathrm{n}$. & $16.3-20.8$ & $19-22$ & $8-11$ & $460-600$ & $235-285$ & $71-88$ & $0-1-3 / 4$ & $158-184$ \\
\hline teshi* & $21.0-27.0$ & $17-24$ & $8-14$ & $393-737$ & $255-329$ & $70-90$ & $0 / 1-4 / 5$ & 154-206 \\
\hline
\end{tabular}

a precloacal-adcloacal-postcloacal (n/n' when asymmetrically arranged); *from original author (see Table 1); ${ }^{1}$ Guerrero and Bain 2011; ${ }^{2}$ Notarnicola et al. 2010; ${ }^{3}$ Bain et al. 1989.

viation $1.3 \%$ ) for $12 \mathrm{~S}$ rDNA and $12.6 \%$ (standard deviation $1.5 \%$ ) for coxI.

PCR screening for Wolbachia was positive.

\section{DISCUSSION}

Nectomys spp. are linked with running water in South America. The five Neotropical species have distinct geographic areas (Wilson and Reeder 2005): N. squamipes (Brants) occurs in the southeast, $N$. apicalis Peters in the west, $N$. rattus (Pelzen) in the Amazonian region, and the two remaining species are restricted to the northern areas, with $N$. magdalenae (Thomas) in the west, and N. palmipes in the east. Litomosoides is at present reported in three Nectomys species. Nectomys squamipes is infected with L. kohnae in Brazil (Sao Paulo) and with L. navonae in Northern Argentina (Misiones, type locality; Chaco, Formosa). Nectomys palmipes is infected with L. taylori in northeast Venezuela. The Litomosoides from Nectomys spp. belong to the sigmodontis type. No distinctive shared characters indicating that they form a particular lineage could be observed among these three Litomosoides species from the same host genus. The molecular analysis indicates L. galizai, from the sigmodontine Oecomys trinitatis tapajinus Thomas from Parà, Brazil, as the closest species. However, it must be stressed that species in the "sigmodontis group" are very closely related, and gene sequencing in combination with morphological studies is necessary to decipher the diversity and evolution of this filarial genus. Presently, this has been achieved for a few species only, not including the parasites of $N$. squamipes.

Regarding the endosymbiont Wolbachia pipientis, its presence was expected, since among the seven Litomosoides species examined to date, L. yutajensis from a mormoopid bat was the only one not to harbour this bacterium (Bain et al. 2008).

Acknowledgements. To S. Boher, G. Cordero and J.L. Moncada for capture of the hosts, which were obtained with Licencia con Fines Cientificos No. 2192 dated June 18, 2007 and the Contrato de Acceso a los Recursos Genéticos No. 33/2007, granted by Ministerio del Ambiente de la Republica Bolivariana de Venezuela. Partial funding by Petroleos de Venezuela S. A. in the project "Evaluación sistémica de las condiciones socio ambientales en un área de producción del Distrito San Tomé, División Oriente". The work was also supported by the European Community grant INCO-CT-2006-032321 and by the MNHN grant ATM: Taxonomie moléculaire: DNA barcode et gestion des collections. We thank Dr. Kerstin Junker for her valuable comments.

\section{REFERENCES}

Bain O., Casiraghi M., Martin C., Uni S. 2008: The Nematoda Filarioidea: critical analysis linking molecular and traditional approaches. Parasite 15: 342-348.
Bain O., Guerrero M., Rodriguez B., Babayan S., Jouvenet N. 2003: Examination of type material of two species of Litomo- 
soides (Filarioidea: Onchocercidae), parasites from bats; taxonomic consequences. Parasite 10: 211-218.

Bain O., Petit G., Berteaux S. 1980: Description de deux nouvelles Filaires du genre Litomosoides et de leurs stades infestants. Ann. Parasitol. Hum. Comp. 55: 225-237.

Bain O., Petit G., Diagne M. 1989: Etude de quelques Litomosoides parasites de rongeurs; conséquences taxonomiques. Ann. Parasitol. Hum. Comp. 64: 268-289.

Bain O., Philipp M., Hoste H., Yvore P. 1991: Animal models in the study of the phenomenon of parasitism: Filariae and other parasites. Ann. Parasitol. Hum. Comp. 66: 64-68.

Brant S.V., Gardner S.L. 1997: Two new species of Litomosoides (Nematoda: Onchocercidae) from Ctenomys opimus (Rodentia: Ctenomyidae) on the Altiplano of Bolivia. J. Parasitol. 83: 700-705.

Brant S.V., Gardner S.L. 2000: Phylogeny of species of the genus Litomosoides (Nematoda: Onchocercidae): evidence of rampant host switching. J. Parasitol. 86: 545-554.

Caballero E. 1939: A new filariid worm from Mexican bats. Trans. Am. Microsc. Soc. 58: 456-458.

Caballero E. 1947: Algunas filarias de mamiferos y de reptiles de las Republicas de Colombia y Panama. An. Inst. Biol. 18: 169-188.

Cardenas M.Q., Lanfredi R.M. 2008: Ultrastructure of reproductive system of female Litomosoides chagasfilhoi MoraesNeto, Lanfredi and De Souza, 1997 (Nematoda: Filarioidea). Parasitol. Res. 102: 1135-1142.

Casiraghi M., Bain O., Guerrero R., Martin C., Pocacqua V., Gardner S.L., Franceschi A., Bandi C. 2004: Mapping the presence of Wolbachia pipientis on the phylogeny of filarial nematodes: evidence for symbiont loss during evolution. Int. J. Parasitol. 34: 191-203.

Casiraghi M., Favia G., Cancrini G., Bartoloni A., Bandi C. 2001: Molecular identification of Wolbachia from the filarial nematode Mansonella ozzardi. Parasitol. Res. 87: 417-420.

Chabaud A.G. 1982: Spectre d'hôtes et évolution des Nématodes parasites de Vertébrés. Mém. Mus. Natl. Hist. Nat., N. Sér., Sér. A, Zool., 123: 73-76.

Chander A.C. 1931: New genera and species of nematode worms. Proc. U.S. Natl. Mus. 78: 1-11.

Cuartas-Calle C., Munoz-Arango J. 1999: Nematodos en la cavidad abdominal y el tracto digestivo de algunos murcielagos colombianos. Caldasia 21: 10-25.

Essuinger H. 1973: The genus Litomosoides Chandler, 1931 (Filarioidea: Onchocercidae) in Colombian bats and rats. J. Parasitol. 59: 225-246.

Ferri E., Barbuto M., Bain O., Galimberti A., Uni S., Guerrero R., Ferté H., Bandi C., Martin C., Casiraghi M. 2009: Integrated taxonomy: traditional approach and DNA barcoding for the identification of filarioid worms and related parasites (Nematoda). Front. Zool. 6: 1-12.

Folmer O., Black M., Hoen W., Lutz R., Vrijenhoek R. 1994: DNA primers for amplification of mitochondrial cytochrome $c$ oxidase subunit I from diverse metazoan invertebrates. Mol. Mar. Biol. Biotechnol. 3: 294-299.

Guerrero R. 2008: Parasite community analysis, a tool for assessment studies. 10th European Multicolloquium of Parasitology Paris, August 24-28, 2008, Abstracts, No. 78.

Guerrero R., Bain O. 2011: Study of types of some species of "Filaria" (Nematoda) parasites of small mammals described by von Linstow and Molin. Parasite 18, in press.
Guerrero R., Bain O., Attout T., Martin C. 2006: The infective larva of Litomosoides yutajensis Guerrero et al., 2003 (Nematoda: Onchocercidae), a Wolbachia-free filaria from bat. Parasite 13: 127-130.

Guerrero R., Martin C., Gardner S.L., Bain O. 2002: New and known species of Litomosoides (Nematoda: Filarioidea): important adult and larval characters and taxonomic changes. Comp. Parasitol. 69: 177-195.

Hall T.A. 1999: BioEdit: a user-friendly biological sequence alignment editor and analysis program for Windows 95/98/NT. Nucleic Acids Symp. Ser. 41: 95-98.

Junker K., Barbuto M., Casiraghi M., Martin C., Uni S., BoomkeR J., BAin O. 2009: Litomosa chiropterorum Ortlepp, 1932 (Nematoda: Filarioidea) from a South African Miniopterid: redescription, Wolbachia screening and phylogenetic relationships with Litomosoides. Parasite 16: 43-50.

Linstow O. von 1899: Nematoden aus der Berliner Zoologischen Sammlung. Mitt. Zool. Samml. Mus. Naturkd. Berlin 1: 5-28.

Mazza S. 1928: Filarideo n. sp. de la cavidad peritoneal de la rata de los cañaverales de Tabacal, Salta. Bol. Inst. Clin. Quir. 4: 628-632.

Moraes Neto A.H.A., Lanfredi R.M., De Souza W. 1997: Litomosoides chagasfilhoi sp. nov. (Nematoda: Filarioidea) parasitizing the abdominal cavity of Akodon cursor (Winge, 1887) (Rodentia: Muridae) from Brasil. Parasitol. Res. 83: 137-143.

MulleR R. 1980: Litomosoides barretti $\mathrm{n}$. sp. from the ashy opossum in Brazil (Nematoda, Filarioidea). Rev. Bras. Biol. 40: $81-83$.

Notarnicola J. 2005: Description of adults and fourth-stage larva of Litomosoides navonae n. sp. (Nematoda: Onchocercidae), a parasite of five species of sigmodontine rodents from northeastern Argentina. Syst. Parasitol. 62: 171-183.

Notarnicola J., Bain O., Navone G.T. 2000: Two new species of Litomosoides (Nematoda: Filarioidea) in sigmodontines (Rodentia: Muridae) from Rio de La Plata marshland, Argentina. J. Parasitol. 86: 1318-1325.

Notarnicola J., Bain O., Navone G. 2002: Litomosoides anguyai n. sp. (Nematoda: Onchocercidae) from Oxymycterus misionalis (Rodentia: Muridae) in the rain forest of Misiones, Argentina. Syst. Parasitol. 52: 129-135.

Notarnicola J., Digiani M.C., Lopez P.M. 2010: Redescriptions of the nematodes Litomosoides patersoni (Mazza, 1928) (Onchocercidae) and Stilesstrongylus stilesi Freitas, Lent, and Almeida, 1937 (Heligmonellidae) parasites of Holochilus chacarius (Rodentia, Cricetidae) from Salta, Argentina. J. Parasitol. 96: 993-1001.

Notarnicola J., Navone G.T. 2009: A new species of Litomosoides Chandler, 1931 (Nematoda: Filarioidea) from the longnosed hocicudo Oxymycterus nasutus Waterhouse (Rodentia: Cricetidae) in Uruguay. Syst. Parasitol. 73: 87-94.

Tamura K., Dudley J., Nei M., Kuma S. 2007: MEGA 4: Molecular Evolutionary Genetics Analysis (MEGA) software versions 4.0. Mol. Biol. Evol. 24: 1596-1599.

Thompson J.D., Gibson T.J., Plewniak F., Jeanmougin F., HigGINS D.G. 1997: The ClustalX Windows interface: flexible strategies for multiple sequence alignment aided by quality analysis tools. Nucleic Acids Res. 24: 4876-4882.

Wilson D.E., Reeder D.M. (Eds.) 2005: Mammal Species of the World. A Taxonomic and Geographic Reference. 3rd ed. Johns Hopkins University Press, Baltimore, 2142 pp. 